\title{
PRINSIP KEHATI-HATIAN NOTARIS DALAM MEMBUAT AKTA AUTENTIK
}

\author{
Oleh \\ Ida Bagus Paramaningrat Manuaba \\ I Wayan Parsa \\ I Gusti Ketut Ariawan \\ Magister Kenotariatan Universitas Udayana \\ Email : Idabagusrama1993@yahoo.com
}

\begin{abstract}
ABSTRAK
Notaris dalam menjalankan tugas dan jabatannya sangat penting untuk melaksanakan prinsip kehati-hatian dalam proses pembuatan akta autentik, mengingat seringnya terjadi permasalahan hukum terhadap akta autentik yang dibuat notaris karena terdapat pihak-pihak yang melakukan kejahatan seperti memberikan surat palsu dan keterangan palsu kedalam akta yang dibuat notaris. Sehingga untuk mencegah terjadinya kejahatan-kejahatan yang dapat menjerumuskan notaris terlibat dalam permasalahan hukum, perlu diatur kembali dalam Undang-Undang Jabatan Notaris tentang pedoman dan tuntunan notaris untuk bertindak lebih cermat, teliti dan hati-hati dalam proses pembuatan akta autentik.

Ada dua isu hukum yang dikaji dalam penelitian ini, yakni (1) bentuk-bentuk prinsip kehati-hatian notaris dalam proses pembuatan akta autentik dan (2) akibat hukum terhadap akta notaris yang dibuat berdasarkan surat palsu dan keterangan palsu. Adapun jenis penelitian yang digunakan dalam tesis ini adalah penelitian hukum normatif yang beranjak dari adanya kekaburan norma dalam pasal 16 ayat (1) huruf a Undang-Undang Jabatan Notaris yang belum jelas mengatur tentang kewajiban notaris untuk bertindak saksama. Pendekatan penelitian terdiri dari pendekatan perundang-undangan, pendekatan konsep dan pendekatan kasus.

Dari hasil penelitian ini disimpulkan, bahwa bentuk-bentuk prinsip kehati-hatian (prudential principle) yang seharusnya dilakukan notaris dalam proses pembuatan akta yaitu, melakukan pengenalan terhadap identitas penghadap, memverifikasi secara cermat data subyek dan obyek penghadap, memberi tenggang waktu dalam pengerjaan akta, bertindak hati-hati, cermat dan teliti dalam proses pengerjaan akta, memenuhi segala teknik syarat pembuatan akta dan melaporkan apabila terjadi indikasi pencucian uang (money laundering) dalam transaksi di notaris, bentukbentuk prinsip kehati-hatian seperti ini sudah seharusnya wajib dilaksanakan notaris agar nantinya notaris dapat mencegah timbulnya permasalahan hukum terhadap akta autentik yang dibuatnya dikemudian hari.

Akibat hukum perjanjian dalam isi akta notaris yang dibuat berdasarkan surat palsu dan keterangan palsu sesuai Pasal 1320 ayat (4) dan Pasal 1335 KUHPerdata yaitu suatu perjanjian yang dibuat berdasarkan sebab yang palsu adalah batal demi hukum (nitiegbaarheid) dan akta yang dibuat kekuatan pembuktiannya terdegradasi dari akta autentik menjadi akta dibawah tangan, akan tetapi tentang kebenaran formal yang terdapat dalam kepala dan penutup akta tersebut tetap mengikat para pihak yang membuatnya.
\end{abstract}

Kata kunci : Prinsip Kehati-hatian Notaris, Akibat Hukum, Surat Palsu.

\section{ABSTRACT}

In carrying out duties and positions, notaries are very important to implement the principle of prudence in the process of making authentic deed. It is due to the frequent legal problems to the authentic deed made by notary; some parties commit crimes through giving a letter and false information into the deed made by notarial. Thus, to prevent the occurrence of crimes which can bring the notary into legal matters, it is necessary to be re-regulated in the Notary Law of guidance about guidance of a notary to act more scrutinize and careful in the process of making authentic deeds. 
There are two legal issues studied in this research, namely (1) notary precautionary forms in the process of authentic deed making and (2) legal consequences of notarial deeds made on the basis of false letters and false statements. The type of research used in this thesis is normative legal research existed based on the vague of the norm in article 16 paragraph 1 letter a of Notary Office Law which is not clear to set about notary obligations to act thoroughly. In addition, the approach used in this research consists of approaches to legislation, conceptual approaches, and case approaches.

Based on the results of this research, it is concluded that the forms of prudential principles that should be done by notary in the process of making the deed is recognizing the identity of the tap, verifying the data subject and object confront scrutinizely, giving grace period for making the deed, acting careffully and scrutinizely the process of creating deed, fulfilling all technical requirements of the deed making and reporting if there is any indication of money laundering in a notary transaction. These prudential principles should be obliged to be executed by a notary in order to prevent the occurrence of legal notary upon the authentic deed made in the future.

Consequences in the contents of notarial deeds made on the basis of false letters and false statements in accordance with Article 1320 paragraph (4) and Article 1335 Civil Code are agreements made on the basis of the false cause is null and void (nitiegbaarheid) and the power of proof is degraded from the authentic deed Becomes a deed under the hands, but the formal truth contained in the head and cover of the deed remains binding on the parties that make it.

Keywords : Prudent Principle of Notary, Legal Consequences, Counterfeit Letter.

\section{PENDAHULUAN}

\subsection{Latar Belakang Masalah}

Di era modern pada saat ini perkembangan kejahatan didalam dunia hukum semakin berkembang karena adanya suatu tujuan dan niat yang tidak baik diinginkan oleh pihak-pihak tertentu. Kejahatan yang sering terjadi dalam profesi hukum adalah salah satunya profesi notaris. Notaris akhir-akhir ini sering dipermasalahkan karena akta autentik yang dibuatnya terindikasi mengandung unsurunsur tindak pidana, hal ini disebabkan karena kurang kehatihatian notaris terhadap para pihak yang menghadap membuat akta autentik yang sering mengambil kesempatan demi keuntungannya sendiri dengan cara melakukan kejahatan seperti memberikan surat palsu dan keterangan palsu kedalam akta yang dibuat oleh notaris.

Terdapatnya permasalahan yang terjadi dalam proses pembuatan akta autentik disebabkan karena dalam Undang-
Undang Jabatan Notaris tidak mengatur secara jelas prinsipprinsip atau langkah-langkah notaris untuk bekerja lebih berhati-hati dalam proses pembuatan akta, sehingga notaris tidak memiliki pedoman dan tuntunan yang berguna untuk mencegah terjadinya kejahatan dalam akta autentik yang dibuat oleh notaris. Kekaburan norma dalam UUJN-P tersebut dapat dilihat dalam Pasal 16 ayat (1) huruf a disebutkan mengenai kewajiban notaris yaitu dalam menjalankan jabatannya, Notaris wajib bertindak amanah, jujur, saksama, mandiri, tidak berpihak, dan menjaga kepentingan pihak yang terkait dalam perbuatan hukum. ${ }^{1}$

Notaris dalam menjalankan tugas dan jabatannya dalam membuat akta tidak luput dari kesalahan atau kekeliruan baik

${ }^{1}$ Habib Adjie, 2015, Hukum Notaris Indonesia (Tafsir Tematik Terhadap UU Nomor 2 Tahun 2014 Tentang Perubahan atas UndangUndang Nomor 30 Tahun 2004 Tentang Jabatan Notaris), PT. Refika Aditama, Surabaya, (Selanjutnya disebut Habib Adjie I ), hal. 1. 
yang disebabkan karena perilaku yang tidak profesional atau memihak salah satu pihak sehingga terjadi permasalahan dalam akta yang dibuatnya. Sebagai pejabat umum yang berwenang untuk membuat akta autentik Notaris seringkali bertindak tidak hati-hati yang berakibat menimbulkan permasalahan hukum, baik dalam ranah hukum pidana maupun ranah hukum perdata, ini disebabkan karena para pihak yang membuat akta autentik memberikan dokumen palsu ataupun memberikan keterangan palsu kepada notaris sehingga menimbulkan permasalahan hukum terhadap akta autentik yang dibuatnya.

Contohnya terjadi kasus pemalsuan surat kuasa menjual palsu yang dilakukan oleh satu pihak dalam transaksi jual beli tanah yang melibatkan Notaris/PPAT di Kota Bandung yang aktanya dinyatakan batal dan tidak memiliki kekuatan hukum berdasarkan Putusan Mahkamah Agung Republik Indonesia Nomor 1137/Pdt/2005. Kasus seperti ini terjadi dikarenakan kurangnya kehati-hatian Notaris dalam proses pembuatan akta autentik sehingga dalam prakteknya sering terjadi kejahatan oleh para pihak seperti pemalsuan identitas, tanda tangan palsu, kwitansi palsu atau sertipikat palsu yang mengakibatkan cacat hukum pada akta yang dibuat oleh notaris. Pemalsuan Surat dan Keterangan Palsu oleh para pihak tersebut dapat merugikan notaris yang sudah menjalankan tugasnya dengan etikad baik malah dianggap turut serta karena para pihak memberikan keterangan palsu kedalam akta autentik yang dibuatnya. Bahkan dalam prakteknya sering terjadi notaris ikut dipanggil baik sebagai saksi bahkan sebagai tersangka karena aktanya yang bermasalah.

Berdasarkan Pasal 16 ayat (1) huruf a UUJN-P yang masih belum jelas mengatur penjelasan kewajiban notaris bertindak saksma dalam pembuatan akta autentik dan untuk menjaga serta melindungi jabatan notaris agar nantinya notaris dapat bertindak lebih berhati-hati dalam membuat akta autentik, penulis dapat memberikan masukan bahwa perlu diperjelas kembali tentang kewajiban notaris untuk melakukan prinsip-prinsip kehatihatian dalam proses pembuatan akta autentik agar nantinya akta yang dibuat tidak menimbulkan permasalahan hukum. Oleh karena itu maka penulis tertarik untuk menyusun Tesis dengan judul "Prinsip Kehati-hatian Notaris Dalam Membuat Akta Autentik".

\subsection{Rumusan Masalah}

Berdasarkan latar belakang yang telah diuraikan diatas, maka dapat ditarik dua permasalahan yang perlu dikemukakan. Adapun perumusan masalah yang akan dibahas dalam penelitian ini, yaitu

1. Bagaimana bentuk-bentuk prinsip kehati-hatian notaris dalam proses pembuatan akta autentik?

2. Bagaimana akibat hukum terhadap akta notaris yang dibuat berdasarkan surat palsu dan keterangan palsu?

\subsection{Tujuan Penelitian}

Tujuan penelitian ini dapat dikualifikasikan atas tujuan yang bersifat umum dan tujuan yang bersifat khusus yang akan dijelaskan sebagai berikut :

\subsubsection{Tujuan Umum}

Secara umum tujuan penelitian terhadap permasalahan diatas dalam kerangka pengembangan ilmu hukum sehubungan dengan paradigma science as a process (ilmu sebagai suatu proses), khususnya dibidang kenotariatan 
adalah untuk menyumbangkan dan mengembangkan pemikiran tentang prinsip kehati-hatian notaris dalam membuat akta autentik mengingat bahwa sering terlibatnya notaris dalam permasalahan hukum, baik dalam ranah hukum pidana maupun ranah hukum perdata terkait dengan akta yang dibuatnya.

\subsubsection{Tujuan Khusus}

Tujuan khusus penelitian dalam penyusunan tesis ini adalah sebagai berikut :

a) Untuk mengkaji dan menganalisis secara jelas bentuk-bentuk prinsip kehati-hatian notaris dalam proses pembuatan akta autentik.

b) Untuk mengetahui dan memahami akibat hukum terhadap akta notaris yang dibuat berdasarkan surat palsu dan keterangan palsu.

\subsection{Manfaat Penelitian}

Setiap

penelitian

yang

dilakukan diharapkan agar dapat memberikan manfaat baik secara teoritis maupun praktis bagi pengembangan ilmu pengetahuan.

\subsubsection{Manfaat Teoritis}

Secara teoritis hasil penelitian ini diharapkan agar memberi manfaat positif bagi perkembangan ilmu hukum, khususnya di bidang kenotariatan yang berkaitan dengan prinsip kehati-hatian notaris dalam membuat akta autentik.

\subsubsection{Manfaat Praktis}

Secara praktis hasil penelitian ini diharapkan dapat memberikan sumbangan berupa masukan bagi notaris agar lebih berhati-hati dalam membuat akta autentik terkait memeriksa setiap dokumen-dokumen dari para pihak dan akta yang dibuatnya sehingga kedepannya tidak menimbulkan permasalahan hukum.

\subsection{Landasan Teoritis.}

Landasan Teoritis merupakan pisau analisa dan landasan berfikir yang bersumber dari suatu teori, asas-asas dan konsep yang sering diperlukan sebagai tuntutan untuk memecahkan berbagai permasalahan dalam sebuah penelitian. Maka dari itu dalam penulisan tesis ini adapun digunakan Teori, Asas dan Prinsip, yaitu :

\subsubsection{Prinsip Kehati-hatian.}

Kehati-hatian berasal dari kata hati-hati (prudent) yang erat kaitannya dengan fungsi pengawasan bank dan manajemen bank. Prudent dapat juga diartikan bijaksana. Apabila dilihat dari prinsip kehati-hatian perbankan (prudent banking principle) sendiri merupakan suatu asas atau prinsip yang menyatakan bahwa dalam menjalankan fungsi dan kegiatan usahanya wajib bersikap hati-hati (prudent) dalam rangka melindungi dana masyarakat yang dipercayakan padanya.

Prinsip kehati-hatian digunakan untuk menjawab rumusan masalah pertama karena dalam Pasal 16 ayat (1) huruf a UUJN-P bunyi pasal tersebut belum menjelaskan kewajiban dan contoh tindakan saksama notaris dalam membuat akta autentik, sehingga kewajiban notaris untuk bertindak saksma yang dimaksud belum jelas dan menimbulkan multitafsir. Oleh karena itu dalam menjalankan tugasnya notaris harus bertindak hati-hati lebih cermat serta teliti dalam memeriksa dokumen maupun keterangan para pihak yang ingin membuat akta autentik agar tidak menimbulkan permasalahan hukum terhadap akta yang dibuatnya dikemudian hari.

\subsubsection{Teori Perlindungan Hukum}

Perlindungan hukum dalam kepustakaan hukum berbahasa belanda dikenal dengan sebutan "rechtbescherming van de

${ }^{2}$ Djoni S. Gazali dan Rachmadi Usman, 2012, Hukum Perbankan, Sinar Grafika, Jakarta, hal. 27. 
burgers".3 Pengertiannya dalam kata perlindungan hukum terdapat suatu usaha untuk memberikan hak-hak yang dilindungi sesuai dengan kewajiban yang harus dilakukan.

Perlindungan

Perlindungan Hukum merupakan suatu hal yang melindungi subyeksubyek hukum melalui peraturan perundang-undangan yang berlaku dan dipaksakan pelaksanaannya dengan suatu sanksi. Perlindungan hukum dapat dibedakan menjadi dua, yaitu : ${ }^{4}$

a) Perlindungan Hukum Preventif adalah perlindungan hukum yang diberikan oleh pemerintah dengan tujuan untuk mencegah sebelum terjadinya pelanggaran. Hal ini terdapat dalam peraturan perundangundangan dengan maksud untuk mencegah suatu pelanggaran serta memberikan rambu-rambu atau batasan-batasan dalam melakukan kewajiban.

b) Perlindungan hukum Represif adalah perlindungan akhir berupa sanksi seperti denda, penjara dan hukuman tambahan yang diberikan apabila sudah terjadi sengketa atau telah dilakukan pelanggaran.

Langkah perlindungan hukum preventif perlu dilakukan oleh notaris dalam membuat akta, mengingat seringnya notaris dihadapkan oleh permasalahan hukum oleh pihak penghadap yang mempunyai niat tidak baik dalam proses pembuatan akta, seperti membuat surat palsu dan mencantumkan keterangan palsu kedalam akta autentik yang dibuat notaris, oleh karena itu perlu diatur kembali dalam UUJN-P tentang prinsip kehati-hatian

${ }^{3}$ Philipus M hadjon,1998, Perlindungan Hukum Bagi Rakyat Indonesia, Bina Ilmu, Surabaya, hal.1

${ }^{4}$ Muchsin, 2003, Perlindungan dan Kepastian Hukum Bagi Investor Di Indonesia, Tesis, Magister Ilmu Hukum Program Pascasarjana Universitas Sebelas Maret, Surakarta, hal. 14. notaris dalam proses pembuatan akta, agar kedepannya notaris dalam melaksanakan tugas dan jabatannya, dapat mencegah timbulnya permasalahan hukum terhadap akta yang dibuatnya dikemudian hari.

\subsubsection{Asas Kepastian Hukum}

Gustaf Radbruch seperti yang dikutip oleh Theo Huijber mengenai kepastian hukum mengemukakan :

Menurut Radbruch dalam pengertian hukum dapat dibedakan tiga aspek yang ketiga-tiganya diperlukan untuk sampai pada pengertian hukum yang memadai. Aspek yang pertama ialah keadilan dalam arti yang sempit. Keadilan ini berarti kesamaan hak untuk semua orang di depan pengadilan. Aspek yang kedua ialah tujuan keadilan atau finalitas. Aspek ini menentukan isi hukum, sebab isi hukum memang sesuai dengan tujuan yang hendak dicapai. Aspek yang ketiga ialah kepastian hukum atau legalitas. Aspek itu menjamin bahwa hukum dapat berfungsi sebagai peraturan yang harus ditaati. ${ }^{5}$

Asas kepastian Hukum digunakan untuk menjawab kepastian hukum dari Pasal 16 ayat (1) huruf a UUJN-P tentang kewajiban notaris untuk bertindak saksama yang masih belum jelas dan menimbulkan multitafsir, sehingga perlu diatur lebih lanjut agar nantinya notaris dapat bertindak berhati-hati dan mencegah permasalahan hukum terhadap akta yang dibuatnya.

\subsubsection{Teori Kekuatan Pembuktian Akta Autentik}

Dalam hal ini ada tiga teori yang harus diperhatikan ketika akta dibuat, teori-teori ini

${ }^{5}$ Theo Huijbers, 2007, Filsafat Hukum dalam Lintas Sejarah, Kanisius, Cetakan Keempat belas, Yogyakarta, hal. 163. 
berkaitan dengan teori kekuatan pembuktian akta autentik, yaitu $:{ }^{6}$

1. Pembuktian Lahiriah (uitwendige bewijskracht)

Menurut Efendi Bachtiar daya bukti lahirnya suatu akta autentik yang memenuhi syarat-syarat yang telah ditentukan maka akta itu berlaku atau dapat dianggap sebagai akta autentik sampai terbukti sebaliknya sesuai dengan asas "acta publica probat sese ipsa”. Daya bukti ini berlaku terhadap siapapun.

2. Pembuktian Formal (formale bewijskracht).

Berdasarkan

pendapat

Notodisoerjo "kepastian bahwa suatu kejadian dan fakta yang tersebut dalam akta betul-betul dilakukan oleh notaris atau diterangkan oleh penghadap. Hal yang pasti ialah tentang tanggal dan tempat akta tersebut dibuat serta keaslian tanda tangan.

3. Pembuktian Materil (materiele bewijskracht).

Daya bukti materil ini membuktikan bahwa antara para pihak yang bersangkutan telah menerangkan bahwa peristiwa itu benar-benar terjadi. Daya bukti materil ini yang dibuktikan bukan saja peristiwa antara para pihak. Melainkan dibuktikan kebenaran dari peristiwa tersebut.

Dalam penulisan ini, teori pembuktian digunakan untuk menjawab tentang kekuatan pembuktian akta autentik, ketiga aspek pembuktian tersebut diatas merupakan kesempurnaan akta notaris sebagai akta autentik dan siapapun terikat pada akta tersebut. Jika dapat dibuktikan dalam suatu persidangan

${ }^{6} \mathrm{R}$ Soegondo Notodisoerjo, 1982, Hukum Nasional di Indonesia Suatu Penjelasan, Rajawali, Jakarta, hal. 55. pengadilan, bahwa salah satu aspek tersebut tidak benar, maka akta yang bersangkutan hanya mempunyai kekuatan pembuktian sebagai akta dibawah tangan atau akta tersebut didegradasikan kekuatan pembuktiannya sebagai akta yang mempunyai kekuatan pembuktian sebagai akta dibawah tangan. Oleh karena itu teori pembuktian penting digunakan untuk mengetahui bagaimana akibat hukum akta autentik yang mengandung unsur-unsur surat palsu dan keterangan palsu karena untuk mengetahui akta yang mengandung cacat hukum penegak hukum perlu melakukan pembuktian terlebih dahulu dalam proses peradilan apakah akta yang dibuat notaris tersebut terdapat unsur-unsur surat palsu atau keterangan palsu.

\subsection{Metode Penelitian}

Metode penelitian merupakan suatu kegiatan ilmiah yang didasarkan pada suatu metode, sistematika dan pemikiran tertentu yang bertujuan mempelajari suatu gejala tertentu dengan jalan menganalisinya, karena penelitian dibidang ilmu-ilmu sosial merupakan suatu proses yang dilakukan secara terencana dan sistematis untuk memperoleh pemecahan masalah dan memberikan kesimpulankesimpulan yang tidak meragukan. ${ }^{7}$ Adapun metode penelitian yang digunakan dalam tesis ini adalah sebagai berikut :

\subsubsection{Jenis Penelitian.}

Untuk menghimpun bahan yang diperoleh guna penyusunan dan pembahasan permasalahan dalam penelitian ini, penulis menggunakan metode penelitian hukum normatif yakni beranjak dari adanya kekaburan norma
${ }^{7}$ Ronny Hanitijo Soemitro, 1988, Metodelogi Penelitian Hukum, Ghalia Indonesia, Jakarta, hal. 13. 
hukum atau asas hukum. ${ }^{8}$ Jenis penelitian hukum normatif digunakan karena beranjak dari adanya kekaburan norma hukum dalam ketentuan Pasal 16 ayat (1) huruf a UUJN-P yang belum jelas mengatur tentang kewajiban notaris untuk bertindak saksama dalam proses pembuatan akta autentik.

\subsubsection{Jenis Pendekatan}

Pendekatan yang digunakan dalam menjawab persoalan yang telah dirumuskan dalam penelitian ini yaitu :

1. Pendekatan Undang-undang (statue approach) .

2. Pendekatan konseptual (conceptual approach).

3. Pendekatan Kasus (case approach).

\subsubsection{Sumber Bahan Hukum.}

Sebagai sumber bahan hukum pokok dari penelitian ini terdiri dari bahan hukum primer, bahan hukum sekunder, dan bahan hukum tersier (sebagai penunjang bahan hukum primer dan sekunder). ${ }^{9}$

\subsubsection{Teknik Pengumpulan Bahan} Hukum.

Teknik pengumpulan bahan hukum yang digunakan dalam penelitian tesis ini diperoleh melalui teknik kepustakaan (study document) denga sistem kartu (card system). yakni dengan cara mencatat dan memahami isi dari masing-masing informasi yang diperoleh dari bahan hukum primer, bahan hukum sekunder dan bahan hukum tersier.

\subsubsection{Teknik Analisa Bahan Hukum.}

Pada teknik penulisan analisis bahan hukum dalam penelitian ini menggunakan Teknik deskripsi dan Teknik Interpretasi (Penafsiran) yaitu :

\footnotetext{
${ }^{8}$ Jhony Ibrahim, 2005, Teori dan Metode Penelitian Hukum Normatif, Surabaya, hal. 284.

${ }^{9}$ Soerjono Soekanto dan Sri Pamudji, 2006, Penelitian Hukum Normatif Suatu Tinjauan Singkat, PT Raja Grafindo Persada, Jakarta Hal.38.
}

a. Teknik Deskripsi

Teknik Deskripsi yaitu uraian apa adanya terhadap suatu kondisi atau posisi dari proposisi hukum atau non hukum. ${ }^{10}$

b. Teknik Interpretasi (Penafsiran)

Teknik interpretasi atau penafsiran menurut Sudikno Mertokusumo yang dikutip oleh Ahmad Rifai merupakan "salah satu metode penemuan hukum yang memberikan penjelasan gambling tentang teks undangundang, agar ruang lingkup kaidah dalam undang-undang tersebut dapat diterapkan pada peristiwa hukum tertentu. $^{11}$ Bentuk interpretasi (penafsiran) yang digunakan dalam penelitian ini adalah interpretasi gramatikal. Interpretasi Gramatikal adalah menafsirkan kata-kata dalam undang-undang sesuai kaidah bahasa dan kaidah hukum tata bahasa. Interpretasi ini merupakan upaya yang tepat untuk mencoba memahami suatu teks suatu aturan perundang-undangan.

\section{TINJAUAN UMUM TENTANG NOTARIS, PRINSIP KEHATI- HATIAN DAN AKTA NOTARIS \\ 2.1 Tinjauan Umum Tentang Notaris dan Prinsip Kehati-Hatian}

\subsubsection{Keberadaan dan Pengertian Notaris}

Terbentuknya

Lembaga Notaris karena adanya kebutuhan masyarakat baik pada zaman dahulu maupun zaman sekarang. Secara kebahasaan Notaris berasal dari kata Notarius untuk tunggal dan Notarii untuk jamak. Notarius merupakan istilah yang digunakan oleh masyarakat Romawi untuk menamai mereka yang melakukan pekerjaan menulis, namun fungsi Notarius pada zaman tersebut

${ }^{10}$ M. Iqbal Hasan, 2002, Pokok-Pokok Materi Metode Penelitian Dan Aplikasinya, Cet. 1, Ghalia Indonesia, Jakarta, hal. 43.

${ }^{11}$ Amiruddin dan H. Zainal Asikin, 2012, Pengantar Metode Peneletian Hukum, Cetakan ke-6, PT. Rajagrafindo Persada, Jakarta, hal. 163. 
berbeda dengan fungsi Notaris pada saat ini. ${ }^{12}$

Jaman Pemerintahan Republik Indonesia merdeka terbagi menjadi 2 (dua) periode atau masa berdasarkan pemberlakuan undang-undang tentang Notaris, yaitu :

a. PJN (Peraturan Jabatan Notaris), sejak merdeka sampai diberlakukannya UUJN (Orde Lama, Orde Baru, Reformasi sebelum Juni 2004); dan

b. Undang-Undang Nomor 2 Tahun 2014 Perubahan atas UndangUndang Nomor 30 Tahun 2004 tentang Jabatan Notaris yang diundangkan sejak tanggal 6 Oktober $2004 .^{13}$

Undang-Undang

Jabatan

Notaris merupakan peraturan hukum dibidang pengaturan notaris. Notaris sebagai jabatan wajib bertindak professional dalam melaksanakan jabatannya sesuai dengan standar jabatan yang diatur dalam Undang-Undang Jabatan Notaris, yaitu memberikan pelayanan yang sebaik-baiknya kepada masyarakat. ${ }^{14}$ Sebagaimana diatur dalam Pasal 1 UUJN-P menyebutkan Notaris adalah pejabat umum yang berwenang untuk membuat akta autentik dan memiliki kewenangan lainnya sebagaimana dimaksud dalam Undang-Undang ini atau berdasarkan undang-undang lainnya.

\subsubsection{Kewajiban, Larangan dan Kode Etik Notaris}

${ }^{12}$ Abdul Ghofur Anshori, 2009, Lembaga Kenotariatan Indonesia (Perspektif Hukum dan Etika), UII Press, Yogyakarta, hal. 7-8.

${ }^{13}$ AA. Andi Prajitno, 2010, Himpunan Peraturan Perundang-Undangan Jabatan Notaris Di Indonesia, Cetakan Pertama, Putra Media Nusantara, hal. 15.

${ }^{14}$ Habib Adjie, 2009, Meneropong Khazanah Notaris dan PPAT Indonesia (Kumpulan Notaris dan PPAT), P.T. Citra Aditya Bakti, Bandung, (Selanjutnya disebut Habib Adjie II ), hal. 3 .
Notaris sebagai pejabat umum pembuat akta autentik tentunya memiliki kewajiban yang harus dijalankan dan tidak boleh bertentangan dengan perundangundangan yaitu Undang-Undang Jabatan Notaris yang diatur dalam pasal 16 UUJN-P. Selain kewajiban yang harus ditaati dan dilaksanakan Notaris sebagai pejabat umum memiliki laranganlarangan, yaitu adapun laranganlarangan seorang notaris yang diatur dalam pasal 17 ayat 1 UUJN-P.

Dalam organisasi Notaris memiliki Kode etik yang memuat kewajiban serta larangan bagi notaris yang sifatnya praktis. Terhadap pelanggaran kode etik terdapat sanksi-sanksi organisasi dan tanggungjawab secara moril terhadap citra notaris baik sekarang maupun yang akan datang. Kode etik notaris ini berlaku bagi serta wajib ditaati oleh setiap dan semua anggota perkumpulan serta semua orang yang menjalankan tugas jabatan sebagai notaris.

\subsubsection{Prinsip Kehati-Hatian}

Dilihat dari kamus besar Bahasa Indonesia kehati-hatian diartikan berhati-hati atau waspada. Kehati-hatian disini erat kaitannya dengan ketelitian, kecermatan dan kesaksamaan yang memiliki arti yang sama, dalam hukum perbankan istilah kehatihatian (prudent) dikaitkan dengan fungsi pengawasan bank dan manajemen bank yang mulai dikenal pada tahun 1980-an. Kata "prudent" itu sendiri secara harafiah dalam bahasa Indonesia berarti bijaksana.

Dalam dunia perbankan istilah ini digunakan untuk prinsip kehati-hatian bank. Oleh karena itu di Indonesia muncul istilah pengawasan atau manajemen bank berdasarkan prinsip kehati-hatian. Prinsip kehati-hatian (Prudential 
Principle) adalah suatu asas atau prinsip yang menyatakan bahwa bank dalam menjalankan fungsi dan kegiatan usahanya wajib bersikap hati-hati dalam rangka melindungi dana masyarakat yang dipercayakan padanya. ${ }^{15}$

Prinsip kehati-hatian yang ada dalam perbankan (Prudential Principle) digunakan karena notaris sebagai pejabat umum, harus memegang teguh prinsip kehati-hatian tersebut, agar tidak menimbulkan permasalahan hukum terhadap akta yang dibuatanya dikemudian hari.

\subsection{Tinjauan Umum Tentang Akta Notaris}

\subsubsection{Pengertian Akta}

Menurut S.J Fockema Andrea dalam bukunya Rechts geleerd handwoorddenboek, kata akta itu berasal dari bahasa latin acta yang berari geschrift atau surat. ${ }^{16}$ Secara umum akta mempunyai dua arti yaitu :

1. Perbuatan (handling) atau perbuatan hukum (rechtshandeling).

2. Suatu tulisan yang dibuat untuk dipakai atau untuk digunakan sebagai perbuatan hukum tertentu yaitu berupa tulisan yang ditunjukan kepada pembuktian tertentu. ${ }^{17}$

\subsubsection{Macam Akta Notaris}

Berdasarkan bentuknya akta Notaris dibagi menjadi dua macam yaitu akta autentik dan akta dibawah tangan, yang dijelaskan sebagai berikut :

\section{a. Akta Autentik}

Akta Autentik yang dalam bahasa Inggris, disebut dengan

${ }^{15}$ Permadi Gandapradja, 2004, Dasar Dan Prinsip Pengawasan Bank, Gramedia Pustaka Utama, Jakarta, hal. 21-22.

${ }^{16}$ S.J. Fockema Andrea, Rechgeleerd Handwoorddenboek, 1951, BIJ J.B. Wolter Uitgevermaat Schappij, N.V. Gronogen, Jakarta, hal. 9. dari:

${ }^{17}$ Widhi Yuliawan, 2013, diakses

http://widhiyuliawan.blogspot.com/ pada hari Kamis, tanggal 9 Pebruari 2017. authentic deed, sedangkan dalam bahasa Belanda disebut dengan authentieke akte van, ${ }^{18}$ yang mana di Indonesia diatur dalam Pasal 1868 KUHPerdata menyebutkan pengertian akta autentik adalah "Suatu akta yang didalam bentuk yang ditentukan oleh undangundang oleh atau dihadapan pejabat umum yang berwenang untuk itu ditempat akta itu dibuat". Sedangkan dalam Pasal 1 angka 7 UUJN-P menyebutkan juga pengertian akta autentik yaitu: "akta notaris yang selanjutnya disebut akta adalah akta autentik yang dibuat oleh atau dihadapan notaris menurut bentuk dan tata cara yang ditetapkan dalam undang-undang ini".

\section{b. Akta di Bawah Tangan}

Berdasarkan Pasal 1874 KUH Perdata menyebutkan bahwa: "yang dianggap sebagai tulisan dibawah tangan adalah akta yang ditandatangani dibawah tangan, surat, daftar, surat urusan rumah tangga dan tulisan-tulisan yang lain yang dibuat tanpa perantaraan seorang pejabat umum". Sedangkan ditinjau dari UndangUndang Jabatan Notaris akta dibawah tangan dapat dibagi menjadi dua yaitu akta dibawah tangan yang dilegalisasi dan akta dibawah tangan diwaarmeken, diatur dalam Pasal 15 ayat 2 huruf a dan b UUJN-P, berbunyi :

a. mengesahkan tanda tangan dan menetapkan kepastian tanggal surat di bawah tangan dengan mendaftar dalam buku khusus;

b. membukukan surat di bawah tangan dengan mendaftar dalam buku khusus;

\subsubsection{Syarat Sahnya Akta Notaris Sebagai Akta Autentik.}

${ }^{18}$ Salim HS., 2015, Teknik Pembuatan Akta Satu (Konsep Teoritis, Kewenangan Notaris Bentuk dan Minuta Akta, Cetakan ke-1, PT. Raja Grafindo Perasada, Mataram, hal. 17. 
Akta Notaris secara khusus diatur dalam ketentuan Pasal 1 angka 7 UUJN-P, Sedangkan pengaturan akta autentik dalam pasal 1868 KUHPerdata, pasal ini menjadi sumber keautentikan suatu akta notaris yang juga adalah dasar legalitas eksistensi dari akta notaris yang mana mempunyai syarat-syarat yakni :

a) Akta itu harus dibuat dihadapan pejabat umum.

b) Akta harus dibuat dalam bentuk ditentukan oleh undang-undang.

c) Akta yang dibuat oleh atau dihadapan pejabat umum yang berwenang untuk itu dan dimana tempat akta itu dibuat. ${ }^{19}$

III. PRINSIP KEHATI-HATIAN NOTARIS DALAM PROSES PEMBUATAN

AUTENTIK

3.1.Bentuk-Bentuk Prinsip Kehatihatian Notaris Dalam Proses Pembuatan Akta Autentik

Seseorang Notaris dipandang sebagai seseorang figure yang keterangan-keterangannya dapat diandalkan dan dapat dipercayai yang tanda tangannya serta segel (capnya) memberi jaminan dan bukti kuat dalam akta autetik yang dibuatnya. ${ }^{20}$ Namun pada saat ini sering terjadi permasalahan hukum dalam pembuatan akta yang dibuat oleh notaris, karena akta yang dibuatnya terindikasi mengandung unsur-unsur pidana karena pihakpihak yang menghadap dalam proses pembuatan akta memberikan dokumen-dokumen atau surat palsu serta mencantumkan keterangan palsu

${ }^{19}$ Putu Mas Maya Ramantini, 2014, Tanggungjawab Notaris Dalam Pembuatan Minuta Akta Yang Dibuat Berdasarkan Keterangan Palsu Oleh Para Pihak, Tesis, Fakultas Hukum Universitas Udayana, Denpasar, hal. 56.

${ }^{20}$ Maria S.W. Sumardjono, 2001, Kebijakan Pertanahan Antara Regulasi dan Implementasi, Cetakan Pertama, Kompas, Jakarta, hal. 14. kedalam akta autentik yang dibuat notaris.

Untuk mencegah notaris terjerat dalam permasalahan hukum, adapun bentuk-bentuk prinsip kehati-hatian yang dapat dilaksanakan Notaris dalam proses pembuatan akta meliputi :

1) Melakukan Pengenalan Terhadap Identitas Penghadap.

Dalam menjalankan tugasnya notaris sebelum memulai membuat akta tentunya dihadapkan oleh para pihak yang ingin membuat akta autentik, tentunya notaris sebelum memasukan identitas para pihak kedalam suatu akta, notaris harus mengecek identitas pihakpihak seperti KTP, KK, atau Passport serta mencocokan foto pemilik Identitas dengan pihakpihak yang membuat akta autentik, agar mencegah pemalsuan identitas terhadap akta yang dibuat notaris.

2) Memverifikasi secara cermat data subyek dan obyek penghadap.

Maksud dan tujuan Memverifikasi adalah memeriksa data-data subyek dari para pihak apakah berwenang dan cakap atau tidak dalam melakukan perbuatan hukum sehingga dapat memenuhi syarat sahnya dari suatu akta seperti, apakah pihak yang bertindak sudah berurumur minimal 18 Tahun atau telah menikah menurut Pasal 39 ayat 1 huruf a UUJNP. Sedangkan bagian dari proses memvalidasi data obyek adalah merupakan bagian proses dalam memeriksa dokumen-dokumen obyek yang dibawa oleh penghadap contohnya memeriksa sertifikat tanah Ke Badan Pertanahan Nasional apakah sertifikat tersebut merupakan sertifikat asli atau palsu atau memang benar atau tidak yang bersangkutan (penghadap) yang memiliki sertifikitat tersebut.

3) Memberikan tenggang waktu dalam pengerjaan akta autentik.

Dalam mengerjakan suatu akta agar menghasilkan akta yang baik sepatutnya notaris memberikan tenggang waktu dalam proses pembuatan akta agar tidak 
terburu-buru dan dapat bekerja secara cermat serta teliti sehingga tidak menimbulkan kesalahan dalam pengerjaan akta notaris.

4) Bertindak hati-hati, cermat dan teliti dalam proses pembuatan akta.

Bertindak berhati-hati, cermat dan teliti dalam proses pembuatan akta katakata yang dituangkan ke dalam akta, karena dalam pelaksanaanya sangat sering terjadi akta yang dibuat notaris sering dipermasalahkan karena kata-kata yang dibuat tidak jelas atau menimbulkan penafsiran.

5) Memenuhi segala syarat teknik pembuatan akta Notaris

Untuk membuat akta notariil yang jauh dari indikasi permasalahan hukum tentunya notaris harus memenuhi syarat formal dan syarat materil dari pembuatan akta notaris berdasarkan Undang-Undang Jabatan Notaris ketentuan mengenai syarat formal dalam pembuatan akta diatur dalam pasal 38 UUJN-P, sedangkan syarat materil yang harus dipenuhi dalam pembuatan akta autentik diatur dalam pasal 1320 KUH Perdata.

6) Melaporkan kepada Pihak yang berwajib apabila terjadi indikasi Pencucian Uang dalam Transaksi di Notaris.

Pada saat ini menunjukan bahwa salah satu tindak pidana pencucian uang yang berasal dari tindak pidana korupsi oleh koruptor seringkali memanfaatkan notaris melalui bidang real estate berupa jual beli tanah maupun bangunan. Contoh saja kasus pencucian uang yang dilakukan oleh Mantan Kepala Korps Lalu Lintas Polri, Inspektur Jendral Djoko Susilo yang melibatkan empat Notaris/PPAT di Jakarta Pusat diperiksa oleh Komisi Pemberantasan Korupsi. ${ }^{21}$

\section{2 . Tugas dan Peran Notaris Dalam Proses Pembuatan Akta Agar Mencegah Notaris Dari Permasalahan Hukum.}

a. Tugas Notaris Dalam Proses Pembuatan Akta

\footnotetext{
${ }^{21}$ Komisi Pemberantasan Korupsi, diakses pada tanggal $30 \quad$ Mei 2017, http://www.kpk.go.id/id/
}

Dalam Kongres INI (Ikatan Notaris Indonesia) yang diselenggarakan di Jakarta Setiawan menjelaskan, Inti dari tugas notaris selaku pejabat umum ialah mengatur secara tertulis dan autentik hubungan hukum antara para pihak yang secara manfaat meminta jasa notaris yang pada dasarnya adalah sama dengan tugas hakim yang memberikan keadilan diantara para pihak yang bersengketa. Tugas notaris dalam menjalankan jabatannya adalah sebagai pihak yang mandiri dan bukan sebagai salah satu pihak dalam membuat akta. Itulah sebabnya dalam menjalankan tugas dan jabatannya selaku pejabat umum notaris harus memperlakukan kliennya sama dalam proses pembuatan akta tanpa adanya salah satu pihak yang dipentingkan.

Dalam Upgrading dan Rakernas II Ikatan Pejabat Pembuat Akta Tanah di Bali, Menurut Syafran Sofyan menjelaskan bahwa terdapat beberapa permasalahan yang dihadapkan Notaris/PPAT dalam membuat akta, antara lain : ${ }^{22}$

a. Para pihak (penjual dan pembeli) tidak menghadap Notaris/PPAT sehingga rentan adanya pemalsuan.

b. Notaris/PPAT tidak membacakan atau menjelaskan isi akta yang akan ditandatangani para pihak, sehingga rentan terjadi permasalahan.

c. Notaris/PPAT tidak membukukan dalam buku register akta (reportorium) atau tidak melaporkan ke Badan Pertanahan Nasional.

d. Notaris/PPAT kurang jeli terhadap identitas pihak penjual, sehingga terjadi kesalahan penjual yang bukan sebenarnya.

e. Notaris/PPAT kurang jeli terhadap keabsahan surat tanah yang diakui milik penjual (terkait Girik/SPPT PBB).

Dari penjelasan yang telah diuraikan diatas menyebutkan bahwa notaris dalam mengemban tugas dan jabatannya

${ }^{22}$ Syafran Sofyan, 2017, “ Mengapa Perlu Perlindungan Terhadap Pejabat Pembuat Akta Tanah ?", Pada Upgrading dan Rakernas II PPAT, Badung, Tanggal 28 April. 
memang tidak mudah dan banyak permasalahan-permasalahan yang riskan bisa dihadapi sehingga notaris sering terjerat dalam permasalahan hukum, maka dari itu sangat penting bagi seseorang notaris menerapkan prinsip kehati-hatian dan bekerja sesuai peraturan perundang-undangan dalam melaksanakan tugas dan jabatannya agar nantinya akta yang dibuatnya tidak berimplikasi pada permasalahan hukum di masa yang akan datang.

b. Peran Notaris dalam Proses
Pembuatan Akta
Peranan seorang notaris dalam memberikan penyuluhan hukum dilakukan dalam rangka meningkatkan pengabdian kepada masyarakat sekaligus memberikan penjelasan kepada para pihak bahwa dalam membuat akta autentik seseorang notaris harus bertindak sesuai koridor hukum agar nantinya akta yang dibuatnya tidak menimbulkan permasalahan. Nasihat yang diberikan notaris harus berdasarkan keyakinan dalam bidang-bidang ilmu yang dikuasainya. Keahlian hukum dibidangnya harus sesuai dengan peraturan perundang-undangan yang berlaku. Pemberian hukum oleh notaris dapat mempengaruhi klien dalam menentukan pilihan untuk menentukan tindakan hukumnya. Dalam kenyataannya banyak notaris yang tidak melaksankan fungsinya untuk melakukan penyuluhan hukum kepada kliennya sehingga mempengaruhi terhadap akta yang dibuatnya yang berdampak menimbulkan permasalahan hukum.

\section{AKIBAT HUKUM AKTA} NOTARIS YANG DIBUAT BERDASARKAN SURAT PALSU DAN KETERANGAN PALSU

\subsection{Pembuktian Akta Autentik Yang} Dibuat Oleh Notaris Berdasarkan Surat Palsu dan Keterangan Palsu

Pada dasarnya pembuktian adalah suatu proses persidangan dimana masingmasing berupaya untuk meyakinkan atau memberi kepastian kepada hakim melalui alat-alat bukti yang diajukan mengenai kebenaran dan ketidak benaran peristiwa atau keadaan tertentu. Notaris dalam hal ini selaku pejabat umum yang memiliki kewenangan untuk membuat akta autentik, sering mendapatkan permasalahan hukum yang dimana aktanya sebagai alat bukti yang memiliki kekuatan pembuktian yang sempurna sering dipermasalahkan karena didalam aktanya mengandung surat palsu dan keterangan palsu sebagaimana dimaksud dalam pasal 263, 264 dan 266 KUHP. Akan tetapi untuk menyatakan tentang adanya kebenaran para pihak yang melakukan pemalsuan surat dan memberi keterangan palsu terhadap akta yang dibuatnya, tentu harus melalui proses pembuktian yang dalam proses pembuktian dalam Hukum Acara Pidana digunakan sistem pembuktian secara negatif, yaitu suatu sistem untuk mencari kebenaran materil seorang hakim dalam sistem pembuktian didepan pengadilan agar suatu pidana dapat dijatuhkan harus memenuhi dua syarat mutlak meliputi adanya bukti yang cukup dan keyakinan hakim.

Dalam hukum perdata akta autentik merupakan alat pembuktian yang sempurna berdasarkan asas acta publica probat sese ipsa, yang berarti suatu akta yang lahir sebagai akta serta memenuhi syarat-syarat yang telah ditentukan maka akta tersebut berlaku serta dianggap sempurna sebagai akta autentik sampai terbukti sebaliknya. Namun untuk mencari suatu kebenaran materil dalam hukum acara pidana tentunya dalam proses peradilan untuk membuktikan bahwa dalam akta autentik yang dibuat notaris mengandung unsur-unsur tindak pidana pemalsuan surat dan keterangan palsu tersebut, baik polisi, jaksa dan hakim harus memperhatikan kebenaran kekuatan pembuktian akta autentik yang dibuat notaris, baik dari kebenaran lahiriah, formal, dan materil sehingga dalam dalam proses pembuktian ditemukan unsur-unsur tindak pidana dalam akta yang dibuat notaris.

Dengan demikian dari penjelasan diatas, untuk dapat membuktikan seseorang melakukan tindak pidana 
pemalsuan surat dan keterangan palsu ke dalam akta autentik yang dibuat notaris, dalam hukum acara pidana digunakan sistem hukum pembuktian negatif berdasarkan pasal 183 KUHAP yang menyatakan bahwa "hakim tidak boleh menjatuhkan pidana kepada seseorang berdasarkan kecuali dengan sekurangkurangnya dua alat bukti yang sah ia memperoleh keyakinan bahwa suatu tindak pidana benar-benar terjadi dan bahwa terdakwalah pelakunya" sesuai alat bukti yang sah mengacu pada pasal 184 KUHP.

Selain itu hakim dalam menjatuhkan putusan harus berdasarkan keyakinannya bahwa orang tersebut dapat dikatakan sebagai pelaku yang memenuhi unsurunsur perbuatan melawan hukum berdasarkan Pasal 263, 264, dan 266 KUHP dengan memperhatikan kembali suatu kebenaran kekuatan pembuktian lahiriah (uitwendige bewijskracht), kebenenaran Pembuktian Formal (formale bewijskracht) dan kebenaran Pembuktian Materil (materiele bewijskrachti), sehingga akta tersebut dapat dikatakan memenuhi unsur-unsur perbuatan melawan hukum berdasarkan tindak pidana pemalsuan surat dengan ketarangan palsu didalam akta notariil.

\section{2 . Akibat Hukum Akta Notaris Yang Dibuat Berdasarkan Surat Palsu Dan Keterangan Palsu.}

Adapun syarat-syarat kebatalan (nietieg) yang diatur dalam KUHPerdata dapat dibagi menjadi dua, yaitu :

a) Dapat dibatalkan (Vernietigbaarheid)

1. Melanggar ketentuan Pasal 1230 ayat 1 KUHPerdata (sepakat mereka yang mengikat diri). Pasal 1320 ayat 1 KUHPerdata menyatakan perjanjian adalah sah apabila diantara para pihak sepakat mengikatkan diri. Tiada sepakat yang sah (cacat kehendak/wilsgbrek ). Dalam KUHPerdata terdapat tiga hal yang menjadi pembatalan perjanjian berdasarkan cacat kehendak, yaitu Kekhilafan (Dwaling), Paksaan (Dwang) dan Penipuan (Bedrog).
2. Melanggar syarat subyektif sahnya perjanjian, yaitu melanggar Pasal 1320 ayat 2 KUHPerdata (kecakapan membuat perjanjian). Melanggar Pasal 1320 ayat 2 KUHPerdata (Cakap bertindak menurut hukum), pasal ini menentukan bahwa perjanjian adalah sah apabila para pihak cakap dalam membuat suatu perjanjian.

b) Batal Demi Hukum (Neitigbaarheid)

1. Melanggar ketentuan Pasal 1320 ayat 3 KUHPerdata (suatu hal tertentu). Suatu hal tertentu yang dimaksudkan adalah bahwa obyek perjanjian tersebut haruslah tertentu, dapat ditentukan yaitu suatu barang yang dapat diperdagangkan dan dapat dietentukan jenisnya secara jelas dan tidak kabur.

2. Melanggar ketentuan Pasal 1320 ayat 4 KUHPerdata (suatu sebab yang halal). Suatu sebab yang halal, apabila perjanjian itu dibuat berdasarkan kepada sebab yang sah dan dibenarkan oleh undangundang dan tidak melanggar ketentuan-ketentuan tentang isi dari perjanjian.

Suatu perjanjian yang tidak memenuhi syarat yang sah sebagaimana diatur dalam pasal 1320 KUHPerdata, baik syarat-syarat subyektif maupun obyektif akan mempunyai akibat-akibat sebagai berikut $:^{23}$

1. "Noneksistensi" apabila tidak ada kesepakatan maka tidak timbul perjanjian

2. "Vernietigbaar" atau dapat dibatalkan, apabila perjanjian tersebut lahir karena adanya cacat kehendak (wilsgebreke) atau karena ketidakcakapan (onbekwaamheid) Pasal 1320 syarat 1 dan 2, berarti hal ini terkait dengan syarat subyektif, sehingga berakibat kontrak itu dapat dibatalkan.

${ }^{23}$ Agus Yudha Hernoko, 2009, Hukum Pejanjian (Asas Proporsionalitas Dalam Kontrak Komersial), Kencana, Cetakan ke-4, Surabaya, hal. 160-161. 
3. "Nietig" atau batal demi hukum, apabila terdapat perjanjian yang tidak memenuhi syarat obyek tertentu atau tidak mempunyai kausa atau kausanya tidak diperbolehkan (Pasal 1320 ayat 2 dan 4), berarti hal ini terkait dengan unsur-unsur obyektifnya, sehingga berakibat perjanjian tersebut batal demi hukum

Dalam Pasal 84 UUJN-P tentang akibat hukum akta yang dibuat notaris batal demi hukum sudah dihapuskan. Namun dalam hukum positif yang berlaku, berdasarkan Pasal 1320 KUHPerdata apabila didalam suatu perjanjian tidak terpenuhinya syarat obyektif dalam pasal tersebut maka akibat perjanjian tersebut batal demi hukum. Selanjutnya dalam Pasal 1335 KUHPerdata ditegaskan bahwa, "Suatu perjanjian tanpa sebab, atau dibuat berdasarkan suatu sebab yang palsu atau yang terlarang, tidaklah mempunyai kekuatan". Adapun sebab yang diperbolehkan maksudnya adalah, bahwa apa yang hendak dicapai para pihak dalam perjanjian atau kontrak tersebut harus disertai etikat baik dan tidak bertentangan dengan peraturan perundangundangan, ketertiban umum, dan kesusilaan sesuai Pasal 1337 KUHPerdata.

Apabila terjadi pemalsuan surat dan keterangan palsu yang diberikan oleh para pihak didalam proses pembuatan akta maka tanggungjawab materil merupakan tanggungjawab dari para pihak yang telah memberikan data palsu maupun keterangan palsu kehadapan notaris. Dan para pihak dapat dituntut dan bertanggungjawab atas Tindak Pidana Surat Palsu dan Keterangan Palsu sesuai Pasal 263, 264 dan Pasal 266 KUHP. Tugas notaris hanya menuangkan keinginan para pihak bukan memastikan kebenaran materil dari data yang dibawa oleh para pihak, sehingga dalam menjalankan tugasnya notaris harus menerapkan prinsip kehati-hatian agar tidak percaya secepat mungkin terhadap pihakpihak yang ingin membuat akta autentik.

Dengan demikian berdasarkan hukum positif yang berlaku apabila suatu akta yang dibuat notaris mengandung unsur-unsur tindak pidana surat palsu dan keterangan palsu oleh para pihak, maka jelas-jelas perbuatan tersebut melanggar Pasal 263, 264 dan 266 KUHP, sehingga sesuai Pasal 1320 KUHPerdata ayat (4), akibat hukum perjanjian dalam isi akta autentik tersebut adalah batal demi hukum atau batal sejak perjanjian tersebut dibuat (nitiegbaarheid) dan akta yang dibuat oleh notaris tersebut menjadi terdegradasi nilai kekuatan pembuktiannya dari akta autentik menjadi akta dibawah tangan akan tetapi tentang kebenaran formal yang terdapat dalam kepala dan penutup akta tetap mengikat para pihak yang membuatnya.

\section{PENUTUP}

\subsection{Kesimpulan}

Sesuai apa yang telah diuraikan dalam bab-bab terdahulu, maka dapat ditarik kesimpulan sebagai berikut :

1. Bentuk-bentuk prinsip kehatihatian yang dilakukan notaris dalam proses pembuatan akta yaitu, melakukan pengenalan terhadap identitas penghadap, memverifikasi secara cermat data subyek dan obyek penghadap, memberi tenggang waktu dalam pengerjaan akta, bertindak hati-hati, cermat dan teliti dalam proses pengerjaan akta, memenuhi segala teknik syarat pembuatan akta dan melaporkan apabila terjadi indikasi pencucian uang 
(money laundering) dalam transaksi di notaris, bentukbentuk prinsip kehati-hatian seperti ini sudah seharusnya wajib dilaksanakan notaris agar nantinya notaris dapat mencegah timbulnya permasalahan hukum terhadap akta autentik yang dibuatnya dikemudian hari.

2. Akibat hukum perjanjian dalam isi akta notaris yang dibuat berdasarkan surat palsu dan keterangan palsu sesuai Pasal 1320 ayat (4) dan Pasal 1335 KUHPerdata yaitu suatu perjanjian yang dibuat berdasarkan sebab yang palsu adalah batal demi hukum (nitiegbaarheid) dan akta yang dibuat kekuatan pembuktiannya terdegradasi dari akta autentik menjadi akta dibawah tangan, akan tetapi tentang kebenaran formal yang terdapat dalam kepala dan penutup akta tersebut tetap mengikat para pihak yang membuatnya.

\subsection{Saran}

Adapun saran yang dapat diberikan berdasarkan kesimpulan diatas adalah sebagai berikut :

1. Diharapkan kepada Pemerintah selaku lembaga legislatif yaitu DPR agar memperjelas kembali pengaturan dalam Pasal 16 ayat (1) huruf a UUJN-P tentang kewajiban notaris untuk bertindak saksama dalam proses pembuatan akta, agar nantinya notaris dalam proses pembuatan akta memiliki pedoman dan tuntunan untuk mencegah timbulnya permasalahan hukum dalam akta yang dibuatnya dikemudian hari.

2. Diharapkan notaris dalam proses dan menerima permintaan pembuatan akta lebih berhati-hati, cermat dan teliti menerapkan aturan hukum yang akan dituangkan dalam akta, serta notaris lebih dahulu dapat memberikan legal advice (penyuluhan hukum) oleh penghadap sesuai ilmu kenotariatan yang dimilikinya, agar akta yang dibuatnya sesuai dengan aturan hukum yang berlaku dan tidak bertentangan dengan peraturan perundang-undangan.

\section{DAFTAR PUSTAKA}

\section{Buku :}

Adjie, Habib, 2015, Hukum Notaris Indonesia (Tafsir Tematik Terhadap UU Nomor 2 Tahun 2014 Tentang Perubahan atas Undang-Undang Nomor 30 Tahun 2004 Tentang Jabatan Notaris), PT. Refika Aditama, Surabaya

, 2009, Meneropong Khazanah Notaris dan PPAT Indonesia (Kumpulan Notaris dan PPAT), P.T. Citra Aditya Bakti, Bandung

Amiruddin, 2012, Pengantar Metode Peneletian Hukum, Cetakan ke-6, PT. Rajagrafindo Persada, Jakarta

Andi, AA. Prajitno, 2010, Himpunan Peraturan Perundang-Undangan Jabatan Notaris Di Indonesia, Cetakan Pertama, Putra Media Nusantara

Anshori, Abdul Ghofur, 2009, Lembaga Kenotariatan Indonesia (Perspektif Hukum dan Etika), UII Press, Yogyakarta

Fockema, S.J. Andrea, Rechgeleerd Handwoorddenboek, 1951, BIJ J.B. Wolter Uitgevermaat Schappij, N.V. Gronogen, Jakarta

Gandapradja, Permadi, 2004, Dasar Dan Prinsip Pengawasan Bank, Gramedia Pustaka Utama, Jakarta

Hadjon, Philipus M,1998, Perlindungan Hukum Bagi Rakyat Indonesia, Bina Ilmu, Surabaya 
Hasan, M. Iqbal, 2002, Pokok-Pokok Materi Metode Penelitian Dan Aplikasinya, Cet. 1, Ghalia Indonesia, Jakarta

Hernoko, Agus Yudha, 2009, Hukum Pejanjian (Asas Proporsionalitas Dalam Kontrak Komersial), Kencana, Cetakan ke-4, Surabaya

Huijbers, Theo, 2007, Filsafat Hukum dalam Lintas Sejarah, Kanisius, Cetakan Keempat belas, Yogyakarta

Ibrahim, Jhony, 2005, Teori dan Metode Penelitian Hukum Normatif, Surabaya

Rachmadi, Usman, Djoni S. Gazali, , 2012, Hukum Perbankan, Sinar Grafika, Jakarta

Salim HS., 2015, Teknik Pembuatan Akta Satu (Konsep Teoritis, Kewenangan Notaris Bentuk dan Minuta Akta, Cetakan ke-1, PT. Raja Grafindo Perasada, Mataram

Sumardjono, Maria S.W., 2001, Kebijakan Pertanahan Antara Regulasi dan Implementasi, Cetakan Pertama, Kompas, Jakarta

Soegondo, R. Notodisoerjo, 1982, Hukum Nasional di Indonesia Suatu Penjelasan, Rajawali, Jakarta

Soekanto, Soerjono, Sri Pamudji, 2006, Penelitian Hukum Normatif Suatu Tinjauan Singkat, PT Raja Grafindo Persada, Jakarta

Soemitro, Ronny Hanitijo, 1988, Metodelogi Penelitian Hukum, Ghalia Indonesia, Jakarta

Makalah Seminar :

Syafran Sofyan, 2017, "Mengapa Perlu Perlindungan Terhadap Pejabat Pembuat Akta Tanah? ”, Pada Upgrading dan Rakernas II PPAT, Badung, Tanggal 28 April.

Artikel dalam Internet :

Komisi Pemberantasan Korupsi, diakses di, http://www.kpk.go.id/id/ pada tanggal 30 Mei 2017

Widhi Yuliawan, 2013, diakses dari: http://widhiyuliawan.blogspot.com// pada tanggal 9 Pebruari 2017.

Peraturan Perundang-undangan :

Undang-undang Dasar Negara Republik Indonesia Tahun 1945.

Kitab Undang-Undang Hukum Pidana dan Kitab Undang-Undang Hukum Acara Pidana, Cetakan Keduabelas, 2013, Sinar Grafika, Jakarta.

Kitab Undang-Undang Hukum Perdata (Burgerlijk Wetboek, R. Subekti dan R. Tjitrosusdibio, Cetakan Ketigapuluh enam, 2005, Pradnya Paramitha, Jakarta).

Undang-Undang Republik Indonesia Nomor 2 Tahun 2014 Tentang Perubahan Atas Undang-Undang Nomor 30 Tahun 2004 Tentang Jabatan Notaris (Lembaran Negara Republik Indonesia Tahun 2014 Nomor 3, Tambahan Lembaran Negara Republik Indonesia Nomor 5491).

Undang-Undang Nomor 10 tahun 1998 tentang perubahan atas Undang-Undang Nomor 7 tahun 1992 tentang Perbankan (Lembar Negara Republik Indonesia Nomor 182 Tahun 1998, Tambahan Lembaran Negara Republik Indonesia Nomor 3790). 